\title{
The change in the researcher's position in the study of shamanism
}

\author{
DOI: https://doi.org/10.30664/ar.111072
}

(C)(Attribution 4.0 International (CC BY 4.0)

S

ince the 1960s, shamanism has become one of the landmarks for a new way of life and a more respectful relationship of humans with nature in the Western world. Both researchers and practitioners regard the foundation of shamanism as being animism - an understanding of the connection of all living beings. The role of the community is highlighted in shamanism as the shaman is expected to work for his community. Shamanistic techniques vary according to the society or place where it is practised. In the study of neo-shamanism in the post-modern world, autoethnographic research has been seen as necessary, especially in order to explore the experience of the shaman. In this article we ask what has changed in the perceptions of the community in the study of shamanism and how this change has influenced the position of the researcher. Our article reflects on the resolution of the diversity and sameness through autoethnography, where the researcher is located not only in the experience, but also in its interpretation - which highlights great challenges in contextualizing the study, in writing on the concepts concerned, and indeed in the entire research process.

\section{Introduction}

Shamanism as a phenomenon has drawn researchers' attention since the nineteenth century. Anna-Leena Siikala (2002: 43), a scholar of traditional Finnish shamanism, writes that 'shamanism is not a religion, but rather a complex of rites and beliefs existing within different religions. There is no

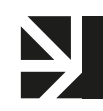

VERTAISARVIOITU

KOLLEGIALT GRANSKAD

PEER-REVIEWED

www.tsv.fi/tunnus single inherited shamanism, nor one current shamanism, but rather shamans operating in different cultures, communities, and time. Therefore, it is preferable to talk about different forms of shamanism. The basis of the shamanic customs and beliefs is in the culture and community where the shaman works. As Graham Harvey (2005: 139) writes, 'shamans are performers of particular roles, skills and arts that require the participation of others.' We concur with him that even though 'shamans shamanise, that does not make them, or the groups for whom they shamanise, members of a religion called Shamanism' (p. 139).

Over the last century, the societies and the contexts in which we can find shamanism have changed drastically. Through this lens we examine shamanism as a historical phenomenon with great local varieties while our focus is on the Finnish context. As there are many shamanisms, they have their own histories. However, science has sought to retrieve common traits and denominations, and thereby a common history. In fact, when we write the history of shamanism, we write the history of the study of shamanism. The two are difficult, even impossible, to keep apart, especially when we are interested in how the position and methods of the researcher of 
shamanism has changed in the study of shamanism.

Research methods have also evolved and developed. To understand the change in the position of the researcher, we have to understand the change both in the context of the research topic, shamanism, and in the scientific methods and concepts linked thereto. The variety of cultures and societies where shamanism is practised, as well as the diversity of shamanisms and the research into them, are extensive. However, in one article it is impossible to conduct an extensive review or comparative research into all the communities or cultures in which shamanism has been practised or researched. We therefore hope that the reader will note that our view of the changes in the communities is intended to serve mainly as an introduction for our more important research issue in this article; that is, how changes in the field should be reflected within the researcher's role.

As the perspective in this article is to some extent - historical, we start with definitions, moving on to the historical perspectives of the study of shamanism. We first open up discussions about the concepts shaman, shamanism and animism, and the historical context of where these come from. We then briefly examine the research of so-called traditional shamanism by taking our examples from the Finnish history of researching shamanism. Only after this do we move on to look at the context of contemporary shamanism in more detail.

There is still a paucity of research on contemporary Western shamanisms; especially the examination of the experience of practitioners is quite limited (see e.g. Wallis 2003: 1, 30; Høst 2001). In reflection of the researcher's role, we will discuss the method, autoethnography, used in our study in the later stages of this article. We will reflect on our experience-based knowledge in practising shamanism. In gender studies, positioning is proportionate to the concept of experience. Experience is defined as inclusion in relevant practices, discourses and institutions (Koivunen and Liljeström 2004: 271, 278). In this article, we locate ourselves in this way in experience. In addition to the interpretation of experience we open up these concepts. By doing this we emphasize the role of the researcher as an interpreter between two fields - the field of researching shamanism and the field of the research topic, namely contemporary shamanism. As the shamanic practitioner and teacher Jonathan Horwitz from the Scandinavian Center for Shamanic Studies (SCSS) says in an interview (Kelly 2017: 98), shamanic knowledge can only be acquired through individual experience, which is 'different from a dogma or a belief system'. He explains that 'this is because shamanism is not a matter of belief, it is a matter of experience' and 'a spiritual path' It is a 'healing spiritual practice'.

The research material used in this study is composed of studies of shamanism, anthropological and religious studies on shamanism, shamanistic literature and years of fieldwork experience amongst shamanic practitioners in Europe. The choice of writings for quotation is based on our own shamanistic education. For example, Jaana Kouri, a researcher of the study of religion, has participated in the workshops of the SCSS, whose methods and teachings are based on core shamanism, even though they differ from the teachings of Michael Harner, the anthropologist and founder of core shamanism, in some perspectives. ${ }^{1}$ Elina Hytönen-Ng, an

1 Two of Harner's colleagues and pupils were Jonathan Horwitz and Annette Høst. They founded the SCSS in 1986. In 2010 
ethnomusicologist and cultural researcher, has studied at the Sacred Trust, led by Simon Buxton, a teacher of shamanism, in England, originally using Harner's model. They have both also participated in courses in Finland led by the shamanism teacher and music therapist Christiana Aro-Harle. In addition to these, the authors' autoethnographic data are included in the research material through research notes and diaries.

\section{Animism and shamanism}

The word shamanism holds within it the history of the research. When shamanic practices in Siberia were presented to Western academic audiences by researchers of Siberian shamanism, the Tungus word shaman became attached to similar practices from other cultures (Eliade 1972: 3; Harvey 2005: 139). Different cultures did not necessarily have a single or similar word describing the person performing shamanic rituals. Yet as Harvey (2003: 3) has noted, the word 'shaman' has now become a 'part of various other languages'. It is therefore important to realize that shamans appear in different cultural contexts, and they are not alike. In Finland the words used for a shaman, or someone who works like a shaman, could be tietäjä, näkijä and noita. In English the first word would be translated as 'a sage', the second word as 'a seer' and the latter one as 'a witch.' The word 'shaman' was taken into the academic discussions to describe the rituals in different cultural contexts and the word then became popularized. During the eighteenth century, research had already developed a more-or-less fixed image of 'shamanism' as a specific type of religion (Stuckrad 2014: 159-60).

Zara Waldebäck joined the team of the centre. They are all teachers of shamanism.
As Susannah Crockford has pointed out, while the word 'shaman' came from Tungus, it has metamorphosed from its original meaning. Therefore, she argues, we need 'to be aware of the etic and emic distinctions, sensitive to cultural differences and biases of interpretation, and understand the positive aspects of Western shamanism for those who participate in it' (Crockford 2010:142). The dichotomy between different kinds of knowledge is commonly expressed by means of the contrast between the 'etic' level of objective description and the 'emic' level, in which cultural subjects make the environment meaningful. Tim Ingold writes that if the emic level is understood as reality constituted in relation to the beings whose environment it is, it is apparent that the world becomes a meaningful place for people through being lived in, rather than by having been constructed along the lines of some formal design' (Ingold 2000: 168, italics in the original).

It is also worth remembering that the community of neither traditional nor modern shamanism is a pre-existing entity that expresses itself via a fixed set of symbols. Community is a formation that comes into being through the circulation and use of shared cultural forms, and that is never complete (see Meyer 2009: 4). Moreover, as Robert J. Wallis (2003: 31) has noted, 'critics of contemporary shamanisms tend to fall into a methodological trap of comparing them with indigenous shamanisms, when the plurality of both, and their engagements, indicate they may or may not be commensurable'. Also, the 'homogenized' core or neo-shamanism, which we will return later, becomes diverse through the activities and reciprocity of users and the spirit world, as an outcome of each person's own shamanic path. This path varies according to the cultural context of the 
shamans and their spiritual experiences. It also changes the discourses of shamanism among practitioners and researchers.

Researchers of shamanism have viewed it as essential to define the concepts used: not only shamanism but also animism. Most teachers, practitioners and researchers of shamanism see animism as the basis of shamanism (see Harvey 2005: 139). Animism as such is, as a scientific concept, one of the oldest terms in the study of religions. Harvey (2005) has explored development in the concept of animism and notes that its definition has changed over time. The older scientific ideas of animism, especially Edward Tylor's, were bedded in the idea of the evolutionary stages of religion, where animism represented the primitive origins of religiosity. According to Harvey the older use of the concept of animism referred to 'a putative concern with knowing what is alive and what makes a being alive' (p. xi).

Harvey suggests a new definition for animism based on his studies in contemporary paganism and indigenous studies. According to his definition of new animism, animists are 'people who recognize that the world is full of persons, only some of whom are human, and life is always living in relationship to others' (Harvey 2005: xi). He specifies that 'persons are those with whom other persons interact with varying degrees of reciprocity, and may be spoken with in contrast regarding objects, which are usually spoken about' (p. xvii). According to him, this is the newer usage, referring to widespread indigenous and increasingly popular 'alternative' understanding that humans share this world with a range of persons, only some of whom are human (p. xi). Similarly, Horwitz (2017: 14) says that 'a lot of the time when people say "shamanic", they actually mean animistic - apperception of the world as it truly is with all things alive and in connection. "Animism" is the awareness of our connection to the world. These things are inseparable?.

Practitioners have defined a shaman by what he does (Horwitz 2017). According to contemporary shamanism as taught by Michael Harner, a shaman is the one who goes into the spirit world and brings power, healing and teachings to whoever needs it. When entering the spirit world, a shaman has a task for which he seeks a solution. Likewise, he also has a task to do when he comes back to his human community. A shaman does not exist without the community or the spirits, as the shaman is the servant and mediator of the human and spirit communities alike. Horwitz specifies that 'just because one is aware of the presence of spirits doesn't mean that they are practicing shamanism; one is practicing shamanism when one comes in contact with them - literally [there is] some kind of intimate relationship going on where humans and spirits are consciously helping each other out' (p. 15).

The work of a shaman is based on the connection of all living things and the possibility of communicating with other beings, who are understood as spirits or persons. Perceptions of the essence of beings vary, depending on the scholar, as well as the shaman, and his culture. The definition of a shaman also has its historical context, depending on the time of the research history, and cannot be fully judged by the today's yardstick. The definitions are reflections of their time and objects. Mircea Eliade's (1964) idea of shamanism as an archaic trance technique does not accommodate an understanding of contemporary or even all traditional shamanism, but it may still be a useful definition in some particular kinds of shamanism.

An example of the complexity of Finnish words referring to shamanic practices 
is well revealed in the discussions by the shamanic community. While Kouri was on the board of Shamaaniseura, the Shamanic Centre of Finland, the network of shamanic practitioners in Finland in the 1990s, the board considered changing the name of the society to an equivalent word in Finnish, such as tietäjä, for example. However, those Finnish words seemed to refer more specifically to only one task of the shamans (Kouri 2020: 235). The use of the 'shaman' or 'shamanism' was also well established among practitioners at the time, both in Finland and elsewhere, and the centre wanted to be part of the international networks of shamans. Some contemporary practitioners also oppose the use of the word 'shaman' and prefer to use culture-specific emic names, such as tietäjä in Finland, or use terms alongside each other (see p. 234). For example, in its homepage a few years ago Pielisen Tietäjäkeskus, a centre for the 'wisdom cultures around Lake Pielinen of North Karelia, Finland', announces its purpose to be 'to promote the continuum of wisdom and shamanic tradition of Finland' (Pielisen Tietäjäkeskus).

Facing especially the diffusion and diversity of modern shamanism, one might ask whether it makes sense to assume a common ground or shared worldview with such varied references to shamanism. In Europe, for example, contemporary shamanism, such as shamanism practised in pagan or neo-shamanism circles, usually does not relate to a homogeneous tradition or culture. As Wallis writes, it is impossible to examine contemporary or "neo-shamanism" as if it were a single entity, since the diversity of practices and practitioners resists such a metanarrative, and there are no fixed boundaries; as well as convergences between indigenous and neo-practices, there are no clear similarities between aspects of neo-shamanisms and a number of traditions, for example in contemporary Paganisms' (Wallis 2003: 32-3). Practitioners prefer to talk not about neoshamanism but for example about modern Western or modern European shamanism (Høst 2001; Stuckrad 2014: 159-60). In contemporary Finland we find a variety of people shamanizing. Some have participated in the internationally run courses of core shamanism following Harner's teachings and others in the more local tradition of Finno-Ugric people or wicca, to give a few examples. In this variety of contemporary shamanism it is as well to pay attention to what is relevant to a particular group and its historical and geographical context where a shaman works.

\section{From studying traditional shamanism to researching contemporary shamanism}

Traditional research on the native cultures has existed since early on, already being in evidence during the nineteenth century. The researchers usually emphasized the rural or uncivilized ways of the natives, colonialism setting the background for the interest. Ethnographic observations were usually made with the pretense of civilizing and educating the natives. These views were very prominent in early anthropology (see e.g. Frazer 1998/1890), while religion was also another matter that influenced the way that the natives were approached.

In the Nordic countries Lars Levi Laestadius was a fine example of this trend. Laestadius, a Lutheran priest living at the beginning nineteenth century, was a Swedish Sámi, also known for establishing the Christian revivalist movement Laestadianism. During his field excursions he also made notes about the mythical worldviews of the Sámi people and their religious beliefs, but also about the shamanic practices of the Sámi (Laestadius 2002). During the nineteenth century the 
Sámi drums were also largely destroyed or collected into European museums (see Joy 2018b). Research on the drums was still being made during the 1990s (Hultkranz 1991).

The tradition created by colonialism continued into the early twentieth century. While the European ethnologists were focusing on the colonies in Africa, Asia and the Americas, the Finnish researchers were directing their attention to ethnic groups closer to home, the Finno-Ugric and other groups, including the Sámi. The research on groups that are ethnically close to Finns continued up until the 1970 s and 1980s; fine examples of this are Anna-Leena Siikala's (1978) and Juha Pentikäinen's work. Pentikäinen has continued to work on shamanism as well as publish on the topic into the twenty-first century (see e.g. Pentikäinen 1998). One of the newest studies of shamanism is the thesis of Francis Joy (2018a) on Sámi shamanism.

In the 1960s, people associated with the 'New Age movement' discovered shamanism. As Kocku von Stuckrad (2014: 16) has summarized, 'the shaman became an indication of a new understanding of humanity's relation to nature, the human's ability to access spiritual levels of reality, and leading a respectful life in the "sacred web of creation"'. The phenomenon was soon to become known in academic parlance as 'neo' or 'modern Western shamanism. The so-called neo-shamans that emerged in the 1960 and 1970 enthusiastically consumed popular anthropology books on shamanisms, such as Mircea Eliade's and Carlos Castaneda's books. In emphasizing the symbolic and cosmological aspects of 'shamanism' and downplaying socio-political diversity, Eliade paved the way for academic interest in shamanism and universalism. Castaneda, on the other hand, was the first person to make the shamanic perspective accessible to Westerners. Castaneda's work encouraged Westerners to become shamans themselves, making shamanism more personal and approachable, even though there is little to warrant belief in Castaneda's work as anthropological 'fact'. Michael Harner (1929-2018), a professor of anthropology, provided a safe and simple technique for making neo-shamanisms a pragmatic possibility, via an easily accessible set of procedures which did not involve the danger of entheogens: 'core shamanism' (Wallis 2003: $38-9,41,43,45)$.

Jan Svanberg (2003) argues that in understanding the origin of neo-shamanism it is essential to consider the intradisciplinary changes of the time, the American counterculture and the ambitions of certain authors to bring about interaction between science and its applications. A particular feature of modern shamanism is that many of the teachers of shamanism had an academic background (p. 27). Therefore, in research on shamanism, there is a mingling of practical terms and concepts from the field and academic textualization. It is good to remember that the role of the author as a shaman or researcher - influences the choice of certain central approaches and concepts in describing the experimental contents of shamanism. The question is how experience-based knowledge is mediated verbally to one's audience. Researchers participated in the shamanistic practices of their objects of study, and conveyed their experiences to scientific and other audiences. The idea that the researcher is able to participate in the lifestyle of the subject holistically, that is the so-called 'going native' idea, reflects the colonial mindsets and attitudes (Wallis 2003: 4-9). Researchers became spiritual experts and combined both cultures of knowledge in their work. They attributed meanings to shamanism that were legitimized 
and turned them into religious practice (Stuckrad 2014: 161, 171-2).

After extensive research both in the field and through anthropological literature, Harner elaborated what he felt to be the common cross-cultural denominators of shamanism. In 1980, he published The Way of the Shaman, which soon became a handbook used around the world for those interested in making a shamanic journey. $\mathrm{He}$ also began to give courses on shamanism. From the very beginning, the technique of core shamanism spread throughout the Western world (Harner 1980: xv; Stuckrad 2014: 171-2). As von Stuckrad reminds us, we have to remember that even though Harner's work has been influential, not all contemporary centres and teachers of modern shamanism see themselves as followers of Harner. Their ideas vary, for example according to how their shamanic practice is related to local traditions. Horwitz can be seen as an example of this diversity, as he was first a colleague of Harner, but in 1986 established his own school with the teacher of shamanism, Annette Høst (SCSS). Their teaching differs in some ways from Harner's, especially in the way they describe working with spirits (Stuckrad 2014: 174-6). At the end of the twentieth century, Horwitz also held his first basic courses in shamanism in Finland with a Finnish anthropologist and teacher of shamanism, Heimo Lappalainen, on whose initiative the Shamanic Centre of Finland was also established.

The transportation of shamanisms from indigenous to Western contexts since the 1960 s is part of a larger process of globalization. Wherever shamanism originated, it is now readily available by electronic means. In the spiritual marketplace thus created it is no surprise that an inevitable individualization is inherent in contemporary shamanisms (Wallis 2003: 58).
Nevertheless, when anthropologists described shamanism, some people recognized similarities and resonances with familiar experience and ideas. Harvey, who examines the period from the viewpoint of paganism, reminds us that 'anthropology gave people a name that could be attached to things they were already doing, and then they added different techniques' (Harvey 2007: 106). Also, the spread of shamanic religious practices as well as ideas to other countries and habitats outside the United States is not a uniform process but involves adaptations to local cultural and historical climates. Neither the studies of the dynamics nor special characteristics of contemporary shamanism in one country, for instance, are necessarily directly transferable to other local contexts. Modern shamans nonetheless study and attend various shamanistic circles as well as ceremonies other than in their homelands. The goals of some shamanistic networks or communities are local or work to strengthen the local culture, while those of other shamanistic networks do not recognize national borders.

As noted already, for example in the case of Harner and others, some researchers of shamanism turned into practitioners and left the academic world. It should also be remembered that rather than simply reading books as 'armchair shamans', many practitioners were - and are - active seekers of shamanic knowledge and the anthropological literature on it (Wallis 2003: 34). Yet as Elina Hytönen-Ng (2016) points out, anthropological literature has usually only been influential at the beginning of the shamanic path, losing its significance as practice strengthens. Dialogue between scholars and shamanic practitioners nonetheless has been advantageous on both sides. In contemporary shamanism the personal experience of a religion often 
outweighs the historical or cultural accuracy for practitioners (Crockford 2010: 154). This has even been viewed as the main doctrinal feature of North American and European shamanism (Stuckrad 2014: 176). Crockford (2010:156) argues that it is the religious experience which for the participants of a ritual constitutes authenticity, 'because only experience is truly our own and provides our own way of flourishing or being fulfilled'.

\section{Changes in the shaman's role}

Individuals are practising shamanism when they come into contact with the spirits, as already noted. This is seen in the intimate relationship where humans and spirits are consciously helping each other out. When shamans shamanize, they mediate spiritual knowledge to their community. In shamanic ontology the community includes human and non-human persons, including animals but also other spirits of nature and spiritual beings.

Somewhat stereotypically, a shaman in an indigenous culture has been understood as a game-resource manager, who understood - as Harvey (2005: 146) notes - that the animals used for food also 'have souls', or perhaps are souls. Consequently, culturally appropriate forms of respect are offered, and further respectful acts promised at and after death. According to Harvey, 'all this is predicated on the ability of humans and animals to communicate, on the reciprocity of their relationships, and mutual intelligibility of their notions and performance of respect' (p. 147). Harvey writes:

Shamans and shamanising provide particularly powerful tests of the boundaries of human attempts to find appropriate ways to live alongside other persons, i.e. of animism. Two major problems recognising one's ontological similarity with others, knowing the necessity of naming them persons, and of attempting to relate respectfully to all who live, are (a) for one some such persons (human or otherwise) are aggressive and even predatory, and (b) must eat at least some of them in order to live. (Harvey 2005: 139-40)

There are not only animist cultures but also cultures within which it is possible to act occasionally as an animist (Harvey 2005: $\mathrm{xv})$. One such is the modern Western culture. Although almost all members of the community in modern society do not deal with the killing of animals or the ethical problems associated with it, an unbalanced relationship of man with his environment is still a basic reason for the shaman's role in their society. Common to all shamanisms is that ill-health is often understood as a state of imbalance of power, and a result of inadequate interaction with other persons, both human and other-than-human (see e.g. Harvey 2005: 149).

Horwitz defines shamanism 'as a spiritual discipline which enables one to directly contact, use, and willingly be used by the spirit power of the Universe, generally for the purpose of healing or restoring balance in some way' (Horwitz 2000). Besides the concepts of balance and power, to understand the idea of spirits and spiritual knowledge the key is the role of a shaman in his or her community, be it a traditional or modern, animist or non-animist, local or global one. It is a fundamental fact to understand that the role of shamans is usually even in modern Western society - a servant of their community, and even shamans nowadays deal with the same 'daily facts of violence and intimacy' (Harvey 2005: 140), which may be different from those of traditional societies. The term 'servant' is to 
be understood as indicating that shamans often act for the benefit of their community. In modern shamanism, the fact that they possibly manage their own well-being through shamanism is also considered to result in common, even universal, good.

Modern society, within which contemporary shamans live, still has the boundaries of life and death, and the questions of health as well as well-being to face. Some of those may be caused by indifference or direct violence to other persons (human or non-human). Shamans are seen as mediators in this human-non-human communication. Their roles and performances, and sometimes their everyday lifestyle, gender, habits and even their very ontologies, mediate between the diverse oppositions and possibilities of their culture (Harvey 2005: 149).

Wallis (2003: 70) points out that where neo-shamans critique society and its conventional religious and social abuse, for instance, they are different from indigenous shamans because their stance is not integrated into a wider community. Yet they may work also for improvement in the conditions of the wider society (p. 70). Persons practising shamanism often have another job to support themselves. The animistic worldview and the advice of spirit guides is seen to transform shamans' worldview and behaviour into a more ethical and spiritual one. The shamanic journey is seen to affect their everyday life and duties in a personal way.

The journey of the shaman is at the centre of shamanizing. In our experience, the holding of various communal ceremonies such as rites of passage or environmental ceremonies is also part of contemporary shamanism. These also connect with the spirit world through various shamanistic techniques. However, their principle is the same. In the rituals or other practices, one or more of the participants are in contact with the spirit world in order to balance some situation or bring advice or healing to someone who needs it, which may also be a non-human target, such as a nature area.

Scholars have debated the authenticity of modern shamanism compared to the so-called traditional forms of shamanism. It is essential to conceive shamanism as a historical phenomenon that has changed and changes as a result of interaction between both humans and material as well as spiritual environments. When we look at shamanism, we must also realize that the community around the shaman has changed. The community in traditional societies was created by the society or village around the shaman, as well as the patients that the shaman worked with. In the contemporary setting the community may now even be a virtual community that never meets in person, and patients may be met only online. The Covid-19 pandemic has emphasized and accelerated this movement into the online environment. As we have noticed during our fieldwork, some shamans or shamanic practitioners work with the spirits for the community and the environment. Some do not work at all with humans but only with the environment. The community has also become a global community as practitioners are trained outside their home country. ${ }^{2}$

While research on neo-shamanism has emphasized the role of the literature in the learning process (Svanberg 2003), the passing on of silent knowledge comes

2 This is also evident in our case, as Hytönen-Ng received her training in Britain between 2011 and 2013 while Kouri has participated in numerous SCSS workshops since 1994 . 
to be questioned. Hytönen-Ng (2016) has pointed out that anthropological literature does not have a very prominent role in the longer learning process within contemporary shamanism. When the role model of a practising shaman is missing in real life, the literature gives the practitioners a first impulse to discover the practices. Later on, the literature's role diminishes as the spirits that the person is working with take over. The non-human community's role is therefore emphasized.

If the context of traditional shamanism, a particular and relatively cohesive culture, is compared to contemporary global culture, one can also think that control or aspiration for security is necessary, when we note that a basic course can only give the student basic tools for making a shamanistic journey. There is seldom an intensive teacher-apprentice system in place and the learning depends on the students' own willingness to take further courses. Their primary teachers are teachers of the spirit world. The fellow students can also act as teachers, reflecting the taught course material and giving a different perspective.

Contemporary shamans in the Western world often conduct their practices alone and in private (Wallis 2003: 60). We stress that contemporary shamans often work separated from like-minded animists, and shamans find their way of life, patients and shamanic vocation in many varied societies. Their often lonely practice is made possible by their connection with the spirit world, which represents their non-human community, and which is actualized in the liminal space of ritual. Whether the shaman works in a traditional or modern society, at the centre of shamanic ritual is the shaman 'journey'. The shaman brings help, advice or healing from the spirit world into this world. ${ }^{3}$ The mediating of this spiritual knowledge takes place through ritual.

\section{The researcher's role in contemporary shamanism and the challenges of carrying out autoethnography in shamanisms}

The study of contemporary shamanism is still rare in Finland, which follows the general pattern of modern shamanism research. ${ }^{4}$ Some research does exist, including the doctoral dissertations of Jan Svanberg (2003) and Marjo Remes (2005) on contemporary shamanism, as well as research articles by Kouri (2020) and Hytönen-Ng (2016), and one that we have written together (Hytönen-Ng and Kouri 2020). Some master's theses on the topic have also been written (e.g. Aarnio 2018; Metsähinen 2020).

As Kouri (2017: 34-5) has summarised, writing as such, interpreting experience in the field and understanding it as a fundamental medium of knowledge has been at the heart of anthropology and ethnographic approaches for decades. After the 1970 and 1980 os and the crisis of representation, reflexivity and making the researcher's position evident in the research text have been an accepted part of ethnography. Hitherto, this was not expected; the researcher observed things only from the outside, objectively. The background of this change was researchers' growing awareness, especially of the relationship between method, language and social reality.

3 During the shamanic journey a shaman travels into the spirit world or the other world. This journey is usually done with the help of a drum (for a closer look at the use and importance of the drum in making a shamanistic journey, see Hytönen-Ng and Kouri 2020).

4 For more detailed information on the Western world, see Wallis 2003. 
Research was now seen as reflexive: while investigating, the researcher was also creating reality as much as producing a description of it. Ethnography was not just a method; ethnographers were now authors, and ethnographies were their literary product. Auto-ethnography seems like the ideal development in this context.

As Kouri (2017: 37-8) notes, autoethnography originally referred to the way ethnographers wrote down autobiographical material or personal fieldwork experiences by talking about 'others'. Thereafter, the autoethnographic research method has evolved in diverse directions. Auto-ethnography stems from a wide and far-reaching 'post-modern' shift in academic thought, which has prompted researchers to be politically self-conscious and self-reflexive (Wallis 2003: 2-4, 9). Overall, autoethnography opposes the dualism of the insideroutsider paradigm. As researchers, we are part of our modern culture, a standpoint that should be regarded as a resource. When studying new religious components in our culture we are already, in a sense, native, and hence insiders within contemporary shamanism.

Usually, it is thought that the researcher as an autoethnographer makes observations from outside the material world, and as a practitioner takes notes from the internal experiences of the spirit world. While carrying out autoethnography the researcher studies his or her own experiences (Tienari and Kiriakos 2020). In reality, internal and external observations and experiences happen at the same time, and this demands self-reflection. Karen McCarthy Brown (2001: 14) describes the work of a researcher, especially in writing, as having an interpretation of different meanings and the networks of meanings that arise from them. The researcher weaves one (researcher's) network of meaning together with another, aesthetically different (research object's) network of meaning (p. 14).

It has been seen that producing ethnographic insights into modern shamanism necessitates a certain degree of qualitative autoethnography and autoanthropology, or 'anthropology at home' (Wallis 2003: 3-6). However, in autoethnography, the researcher's experiences become part of the research material. Firstly, at shamanic rituals, involvement is all or nothing. Shamanic journeys cannot easily be 'observed' or 'revealed'. Whether, for example, the shaman is merged with the spirit helpers is not necessarily visible to the outside observer. Thus, in 1994 Kouri participated in a basic shamanic course in Sweden organized by the SCSS and taught by Horwitz. Over an extended four-day course it took her several days to accomplish the shamanic journey. Over the last days she followed the teachers' advice to change her position so that her feet, not head, were towards the centre of the circle, where the drummer was. It made a difference. When the drumming began, Kouri felt that the sound of the drum went through her soles into her whole body, and at the same time she heard birches singing and her journey started. She 'put her head on the self' for a while, as Horwitz advised, and stopped the logical dialogue inside her head. For Hytönen-Ng the merging appeared only in a slight shift of balance. Studying one's own bodily experiences in her example highlights the small internal changes within the ritual instead of major externally visible characteristics.

Auto-ethnography also makes use of tacit knowledge that is usually hard to pinpoint with words. Tacit, or silent, knowledge is part of experience-based knowledge. Tacit or silent knowledge refers to the natural knowledge, experience and competence that people in their practices 
and activities depend on, but which is difficult to enunciate. According to Hannele Koivunen (1997: 78) silent knowledge includes all genetic, archetypal and experiential knowledge that humans possess. It is present holistically: it is hand skill, skin knowledge and knowledge of the deep layers of the brain (p. 9). Michael Polanyi distinguishes between two dimensions of knowledge. One is personal, tacit knowledge, and the other is explicit, focusing on 'something' knowledge. Awareness of tacit knowledge he calls an auxiliary or awareness 'of something'. Focused knowledge always needs tacit knowledge as its constituent. Tacit knowledge is not static, but intentional imagining. These auxiliary elements jointly carry the meaning of a thing (Polanyi and Prosch 1975: 33-5, 57). In spiritual practices, such as shamanism, part of the tacit knowledge is or has been born as a result of co-working in and with the spirit world and its non-human actors, spirits.

During the shamanic ritual the autoethnographer of shamanic experiences is in a liminal space (see van Gennep 1960). In order to understand the experience of liminal space, one should dismantle the idea of the inner and outer world. Firstly, during the shamanistic ritual the shaman is both on the journey in the spirit world and also in the material place where the ritual is held. Secondly, the direction of each step in the shamanic path is determined by what happens to the shaman in his or her everyday, often animistic, way of life, as well as by the individual experiences in the spirit world, which reciprocally affect the shaman's perceptions and way of life. Here autoethnographic biography and the study of the oral history of shaman circles is useful for research.

Auto-ethnography allows us to identify meanings shared among subjects and within the research community, and also, in the case of the making of spiritual meaning, as in shamanism, to verbalize interactions, for example during the ritual and especially during the shaman journey between the human and the non-human (Kouri 2020: 230-1; Wallis 2003: 6). The shaman works in a community with both human and nonhuman actors. Spiritual knowledge is conveyed in the ritual of the shaman's journey between the two. Also, autoethnographers who study shamanism move between several different communities; thus their role as interpreters of their spiritual experiences are emphasized.

In autoethnography, the target is to understand the general by examining the individual and specific. Therefore, autoethnography questions the individual self and requires rewriting of the self and community, as Deborah E. Reed-Danahay says (1997: 4). At the same time, for example in this article, as researchers we move from generalizations of shamanism towards the context, experience and interpretation of the contemporary practitioner of shamanism.

\section{Discussion}

In this article we have examined how changes in the field should be reflected within the researcher's role. To get a grip on this, we have reviewed how the position and methods of the researcher have changed in the study of shamanism over the years. When looking into the historical developments within the study of shamanism, it is possible to see a shift in the perspectives. While a century ago the focus was on observing the indigenous cultures and the habits as well as beliefs that the natives had, the current trends in research emphasize a more self-reflexive take on study. One approach is to trace this back to the major shift that Michael Harner with 
his contemporaries forged on the study and practice of shamanism in the Western world. As contemporary shamanic practices became well known and accepted within Western societies, the society that had traditionally surrounded the shaman also changed. Neo-shamanism found its ways and meanings within contemporary societies that were radically different from the societies that were encountered in traditional shamanism.

At the same time the research methods were developing as the study of the 'other' became questionable while the criticism of colonialism shifted the focus closer to home. More recently the focus in the study of one's own culture has turned towards the researchers themselves. They could now look at their own society and study it, but also - in the later stages of this development - start to study their own experiences as part of a particular society. This leads to the use of autoethnography. With the help of this inside knowledge, which includes corporeal knowledge, a deeper understanding of certain cultural forms could be reached.

In addition to the fact that in reflexive ethnography researchers are seen to be located within their experience, in autoethnography, researchers are located in their interpretation of the experience, concepts and other material of their research, both their own and of their field more widely. It could be said that in auto-ethnography, researchers are in two fields at the same time: the field of their subject and the field of research. They are insiders in both. Therefore, the meaning of interpretation is emphasized: auto-ethnographers interpret the understanding of the same concepts used by scholars and practitioners for themselves and other scholars alike. Here is the signficance of auto-ethnography in modern shamanism and other spiritual movements to researchers and other readers. Auto-ethnographers act as interpreters of the experience-based knowledge of the field and the spiritual world they convey. The description of experiences of auto-ethnographers can highlight the contribution of different human and non-human actors in the meaning-making process in which they are involved.

The challenge of modern shamanism is in its high diversity, and the personality as well as variety of the experiences of practitioners. In a situation like this, the importance of contextualization is emphasized. It is realized in autoethnography in locating the researcher within his or her own body and shamanistic life path. The more that contextualized knowledge is obtained through studies and also through nonscientific biographies and other materials, the more accurately we can understand the specificities of modern shamanism.

Jaana Kouri, Ph.D. and M.Ed., is a researcher in the study of religions at Åbo Akademi University. She is interested in the relationships between humans and their environment. Her re-

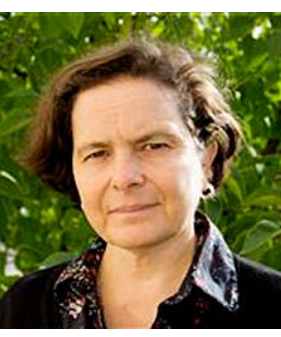
search areas include on the one hand the Baltic Sea region's environmental heritage, and on the other hand shamanism. She is also a word-art instructor and explores the possibilities of creative writing as part of research. Her latest publication on shamanism is the article 'Matka henkimaailmaan ja takaisin. Nykyshamanismi kuvittelun tekniikkana' (2020). She is the co-editor (with Aila Viholainen and Tiina Mahlamäki) of Uskonto ja kuvittelu. Taustoja, tulkintaa ja sovelluksia (SKS 2020) and (with Tuomas Räsänen and Nina Tynkkynen) Muutoksen tyrskyt ja kotirannan mainingit. 
Kulttuurisia näkökulmia merentutkimukseen (SKS 2020). Her latest article is written with Savitri Yetoo, 'Voicing and visualizing change: perceptions of environmental heritage in the Baltic Sea region' in Heritage (2021).

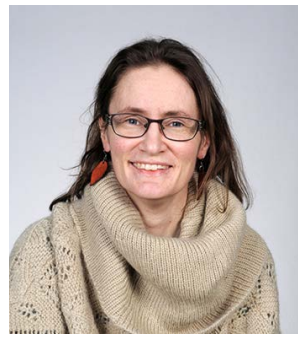

Elina Hytönen- $\mathrm{Ng}$ is an ethnomusicologist and cultural researcher, who holds a doctorate in culture research, specializing in musicology, at the University of Eastern Finland and is a docent in ethnomusicology at the University of Turku. She has specialized in research on musical experiences and performance venues in the contemporary British jazz scene, but has also studied musical experiences related to contemporary shamanism. She has been an academic visitor at the Faculty of Music, University of Oxford, and a visiting research fellow at King's College London. She is currently the primary investigator on a three-year project (2021-4) focusing on lament rituals in contemporary Finnish society.

\section{References}

\section{Sources}

Harner, Michael. 1980. The Way of the Shaman. A Guide to Power and Healing (San Francisco, CA: Harper \& Row).

Horwitz, Jonathan. 2000. 'Shamanic states of consciousness or: what am I doing here?, Scandinavian Center for Shamanic Studies, $<$ http://www.shamanism.dk/shamanicconsciousness.htm $>$ (accessed 19.4.2017).

Horwitz, Jonathan. 2017. 'All life is connected. The shaman's way', Scandinavian Center for Shamanic Studies, <http://www.shamanism.dk/allifeisconnected.htm> (accessed 19.4.2017).

Høst, Annette. 2001. 'Modern shamanic practice. Thoughts on "neo shamanism", "core shamanism", "urban shamanism" and other labels', originally published as 'What's in a name? Neo shamanism, core shamanism, urban shamanism, modern shamanism or what?', Spirit Talk 14 (2001): 3-6, <http:// www.shamanism.dk/modernshamanism. htm $>$ (accessed 19.4.2017).

Kelly, Karen. 2017. 'Walking with the spirits. Karen Kelly talks to Jonathan Horwitz', Sacred Hoop. Celebrate the Circle of Life. Special Issue: Special Guide to Shamanism (2017): 98-9, <http://www.sacredhoop. org/Free-Guide-To-Shamanism/SacredHoop-Free-Guide-To-Shamanism.pdf $>$ (accessed 19.4.2017).

Pielisen Tietäjäkeskus [webpage], <https:// www.tietajakeskus.org/english> (accessed 1.12.2021).

SCSS, Scandinavian Center for Shamanic Studies [webpage], <http://www.shamanism. $\mathrm{dk}>$ (accessed 1.12.2021).

Shamaaniseura [webpage], <https://www. shamaaniseura.fi $>$ (accessed 1.12.2021)

\section{Literature}

Aarnio, Susanna. 2018. “"Mikään ei ole ulkopuolella kaiken”. Tieto, tila ja laulu Johannes Setälän elämässä ja taiteessa’, master’s thesis, University of Turku.

Crockford, Susannah. 2010. 'Shamanisms and the authenticity of religious experience, Pomegranate 12(2):139-58.

Eliade, Mircea. 1964. Shamanism: Archaic Techniques of Ecstacy, trans. from the French by Willard R. Task (Princeton University Press).

Eliade, Mircea. 1972. Shamanism: Archaic Techniques of Ecstasy, revised and enlarged edn (Princeton University Press).

Frazer, James George. 1998/1890. The Golden Bough: A Study in Magic and Religion (Oxford University Press), first published in 1890 .

Gennep, Arnold van. 1960. The Rites of Passage (The University of Chicago Press).

Harvey, Graham. 2003. 'General introduction', in Shamanism. A Reader, ed. Graham Harvey (New York: Routledge), 1-24.

Harvey, Graham. 2005. Animism. Respecting the Living World (London: Hurst).

Harvey, Graham. 2007. Listening People, Speaking Earth. Contemporary Paganism, 2nd edn, corrected and expanded (London: Hurst).

Hultkranz, Åke. 1991.'The drum in shamanism: some reflections', in The Saami Shaman Drum, eds. Tore Ahlbäck and Jan Bergman (Stockholm: Almqvist \& Wiksell International), 9-27.

Hytönen-Ng, Elina. 2016. 'The role of 
anthropological literature on contemporary shamanic practices', Anthropological Journal of European Cultures 25(1): 47-63, doi: <https://doi.org/10.3167/ ajec.2016.250104>.

Hytönen-Ng, Elina, and Jaana Kouri. 2020. 'Rumpu nykyshamanismissa. Tapaustutkimus luontoyhteydestä, Hybris 2020. Luonto, $<$ https://hybrislehti.net/rumpu-nykyshamanismissa-tapaustutkimus-luontoyhteydest>.

Ingold, Tim. 2000. The Perception of the Environment: Essays in Livelihood, Dwelling and Skill (London: Routledge).

Joy, Francis. 2018a. Sámi Shamanism, Cosmology and Art as Systems of Embedded Knowledge (Rovaniemi: University of Lapland).

Joy, Francis. 2018b. 'The disappearance of the sacred Swedish Sámi drum and the protection of Sámi cultural heritage, Polar Record 54(4): 255-66, doi: <https://doi. org/10.1017/Soo32247418000438>.

Koivunen, Anu, and Marianne Liljeström. 2004. 'Paikantuminen' in Avainsanat. 10 askelta feministiseen tutkimukseen, eds. Anu Koivunen and Marianne Liljeström (Tampere: Vastapaino), 271-92, first published in 1996.

Koivunen, Hannele. 1997. Hiljainen tieto (Helsinki: Otava).

Kouri, Jaana. 2017. Vesi kuljettaa ääntä. Autoetnografinen tutkimus Lypyrtin kylän historiantuottamisesta (University of Turku).

Kouri, Jaana. 2020. 'Matka henkimaailmaan ja takaisin', in Kuvittelu ja uskonto. Taustoja, tulkintaa ja sovelluksia, eds. Aila Viholainen, Jaana Kouri, and Tiina Mahlamäki (Helsinki: SKS), 226-53.

Laestadius, Lars Levi. 2002. Fragments of Lappish Mythology, eds. Juha Pentikäinen and K. Börje Vähämäki (Beaverton, ONT: Aspasia Books), original manuscript written between 1838 and 1845 .

McCarthy-Brown, Karen. 2001. Mama Lola: A Vodou Priestess in Brooklyn, 3 rd edn, Comparative Studies in Religion and Society (Berkeley and Los Angeles: University of California Press), first published in 1991.

Metsähinen, Hanne. 2020. “"Se vois antaa meille kaikille yksilöille ja yhteisöille ja yhteiskunnille sielullisen elon takaisin." Sielunmenetys ja -palautus nykyshamanismissa', master's thesis (University of Helsinki), <https:// helda.helsinki.fi/handle/10138/320698>.

Meyer, Birgit. 2009. 'Introduction. From imagined communities to aesthetic formations: religious meditations, sensational forms, and styles of binding, in Aesthetic Formations, Religion/Culture/ Critique, ed. Birgit Meyer (New York: Palgrave Macmillan), 1-30, doi: <https://doi. org/10.1057/9780230623248_1>.

Pentikäinen, Juha. 1998. Samaanit. Pohjoisten kansojen elämäntaistelu (Helsinki: Etnika).

Polanyi, Michael, and Harry Prosch. 1975. Meaning (The University of Chicago Press).

Reed-Danahay, Deborah E. 1997: 'Introduction', in Auto/Ethnography. Rewriting the Self and the Social, ed. Deborah E. Reed-Danahay (Oxford: Berg), 1-17.

Remes, Marjo. 2005. Katseen kulttuuriset rajat. Shamanismista uusshamanismiin (Rovaniemi: University of Lapland).

Siikala, Anna-Leena. 1978. The Rite Technique of the Siberian Shaman, FF Communications 178 (Helsinki: Academia Scientiarum Fennica).

Siikala, Anna-Leena. 2002. Mythic Images and Shamanism: A Perspective on Kalevala Poetry, FF Communications 280 (Helsinki: Academia Scientiarum Fennica).

Stuckrad, Kocku von. 2014. The Scientification of Religion: An Historical Study of Discursive Change, 1800-200o (Boston: De Gruyter).

Svanberg, Jan. 2003. Schamantropologi i gränslandet mellan forskning och praktik. En studie av förhållandet mellan schamanismforskning och neoschamanism (Åbo Akademi University).

Tienari, Janne, and Carol Kiriakos. 2020. 'Autoetnografia', in Laadullisen tutkimuksen näkökulmat ja menetelmät, eds. Anu Puusa and Pauli Juuti (Helsinki: Gaudeamus), 282-95.

Wallis, Robert J. 2003. Shamans/Neo-shamans: Ecstasies, Alternative Archaeologies and Contemporary Pagans (London: Routledge). 